\title{
Comparative Antioxidant Activity and Volatile Oil Composition of Leaves and Fruits of Thuja orientalis Growing in Egypt
}

\author{
Abeer MOAWAD and Elham AMIN* \\ Department of Pharmacognosy, Faculty of Pharmacy, Beni-Suef University, Beni-Suef 62514, Egypt
}

('Corresponding author's e-mail: elhambns@yahoo.com)

Received: 9 November 2016, Revised: 16 September 2018, Accepted: 16 October 2018

\begin{abstract}
Thuja orientalis L. (Cupressaceae) is an evergreen arbor that is distributed throughout Northeast Asia as a common ornamental plant. The volatile oil of leaves and fruits of $T$. orientalis growing in Egypt was prepared by hydro-distillation followed by GC-MS analysis in order to compare between their compositions. Results revealed that fruits are richer in monoterpenes $(62.5 \%)$ while leaves are richer in sesquiterpenes (57\%). The major components in leaf oil are; $\alpha$-cedrol (15.8\%), $\beta$-caryophyllene $(15 \%)$, $\alpha$-humulene $(10.7 \%)$, d-limonene (7.3\%), $\alpha$-pinene $(6.9 \%)$, $\beta$-myrecene $(5.9 \%)$ and $\alpha$-terpinolene $(5.2$ $\%)$. On the other hand, fruit oil contains $\alpha$-pinene $(11.3 \%)$, $\alpha$-cedrol $(11.2 \%)$, $\beta$-myrecene $(9.6 \%)$, geranyl acetate $(9 \%)$ and $\beta$-caryophyllene $(8.9 \%)$ in major amounts. Comparison between the oil content in the Egyptian conifer and other reported conifers worldwide is also discussed. Comparative determination of total phenolic content (TPC), total flavonoids content (TFC) and anti-oxidant activity of alcoholic extract of both leaves and fruits showed that fruits content of flavonoids $(0.6267 \pm 0.026 \mathrm{mg} \mathrm{RE}$ $/ \mathrm{g})$ is double the content of the leaves $(0.3069 \pm 0.019 \mathrm{mg} \mathrm{RE} / \mathrm{g})$. Similarly, fruits contain higher phenolic content $(0.75 \pm 0.007 \mathrm{mg} \mathrm{GE} / \mathrm{g})$ compared to $0.51 \pm 0.007 \mathrm{mg} \mathrm{GE} / \mathrm{g}$ in leaves. Also, fruits extract exhibited higher anti-oxidant activity $(2.3516 \pm 0.0 \mathrm{mg} \mathrm{AEAC} / \mathrm{g})$ than leaves $(1.2734 \pm 0.0022 \mathrm{mg} \mathrm{AEAC} / \mathrm{g})$. The extracts of $T$. orientalis could be a valuable material for pharmaceutical industry.
\end{abstract}

Keywords: Thuja orientalis, volatile oil, total phenolic, total flavonoids, DPPH

\section{Introduction}

Thuja orientalis L. [=Biota orientalis (L.) Endl., Platycladus orientalis (L.) Franco] (Cupressaceae) is an evergreen arbor that is distributed throughout Northeast Asia as a common ornamental plant. This plant has been used as a traditional medicine for the treatment of various inflammatory diseases such as dermatitis, gout and chronic tracheitis. A new labdane diterpene from $T$. orientalis inhibits the inflammatory responses by the suppression of NF-kB activity and ERK phosphorylation [1]. T. orientalis hot water extract promoted hair growth [2] and quercetrin isolated from the leaves has antioxidant activity and inhibits aldose reductase enzyme [3]. The antioxidant activity of some Iranian conifers including $T$. orientalis was estimated using the ferric thiocyanate method and thiobarbituric acid method [4]. The leaves also have molluscicidal activity against fresh water snail Lymnaea acuminata [5]. The essential oil from the leaf is an important natural product which is used in fragrance, air freshener, deodorizer and aromatherapy [6]. Several reports were found discussing the chemical composition of the oil of $T$. orientalis growing in China [6-10], Iran [11-13], Vietnam [14], Pakistan [15,16], Austria [17], Nigeria [18], India [19-22], Turkey [23], Tunisia [24] and Syria [25]. Accordingly, the aim of this study is to investigate the composition of oil of $T$. orientalis growing in Egypt and to compare between leaves and fruits, considering their volatile oil compositions, total phenolic content, total flavonoid content and their antioxidant activity. Moreover the composition of the oil distilled from the Egyptian plant is compared with other previously reported oil compositions of $T$. orientalis collected from different localities. 


\section{Materials and methods}

\section{General experimental procedures}

Volatile oil analysis was performed using Hewlett-Packard 6890/5972 system equipped with an Aglient mass spectrometric detector, with a direct capillary interface and fused silica capillary column HP-5 ms $(30 \mathrm{~m} \times 0.32 \mathrm{~mm} \times 0.25 \mu \mathrm{m}$ film thickness). Shimadzu UV-visible (UV-1650) spectrophotometer was used, Chemicals for the spectrophotometric analysis; absolute ethanol, $\mathrm{NaNO}_{2}$, $\mathrm{NaOH}$ were of analytical grade. $\mathrm{AlCl}_{3}$, Folin Ciocalteu reagent, DPPH, gallic acid and rutin were purchased from Sigma Aldrich Chemicals, Germany. Distillation of oil was performed using Clavenger apparatus.

\section{Plant material}

Fresh fruits and leaves of $T$. orientalis were collected from Beni-Suef University Campus (May 2015). The authenticity of the collected plant was confirmed by Dr. Abdelhalim Mohamed (Plant Taxonomy Department, Agricultural Research Institute, Egypt). Voucher specimen was deposited at the Department of Pharmacognosy, Faculty of Pharmacy, Beni-Suef University. Fresh samples were used for volatile oil distillation while dried samples were extracted quantitatively with $80 \%$ methanol for assessment of TPC, TFC and antioxidant activity.

\section{Isolation of the volatile oils}

Fresh leaves and fruits (100 g) were separately crushed by electric mixer and hydro-distilled in a Clevenger apparatus for $6 \mathrm{~h}$. The produced oil was collected, dehydrated over anhydrous sodium sulfate and stored in a sealed vial at $4{ }^{\circ} \mathrm{C}$ until required.

\section{Volatile oil gas chromatography-mass spectrometry analysis}

Volatile oil analysis was performed by GC/MS using a Hewlett-Packard 6890/5972 system with a HP-5 ms capillary column $(30 \mathrm{~m} \times 0.32 \mathrm{~mm} ; 0.25 \mu \mathrm{m}$ film thickness). Helium was used as carrier gas at approximately $1.0 \mathrm{ml} / \mathrm{min}$., pulsed splitless mode. The solvent delay was $3 \mathrm{~min}$ and the injection size was $1.0 \mu \mathrm{l}$. The mass spectrometric detector was operated in electron impact ionization mode with an ionizing energy of $70 \mathrm{ev}$, scanning from $\mathrm{m} / \mathrm{z} 50$ to 500 . The ion source temperature was $230{ }^{\circ} \mathrm{C}$. The electron multiplier voltage (EM voltage) was maintained $1250 \mathrm{~V}$ above auto tune. The instrument was manually tuned using perfluorotributyl amine (PFTBA). The GC temperature program was started at $60{ }^{\circ} \mathrm{C}(2 \mathrm{~min})$ then elevated to $280{ }^{\circ} \mathrm{C}$ at a rate of $8{ }^{\circ} \mathrm{C} / \mathrm{min}$. The detector and injector temperature were set at $300{ }^{\circ} \mathrm{C}$ and $280^{\circ} \mathrm{C}$, respectively.

\section{Identification of the compounds}

The separated peaks were tentatively identified by comparing mass spectra and retention indices with those recorded in Wiley and Wiley Nist mass spectral databases built up from pure substances and components of known essential oils.

\section{Determination of total phenolic content (TPC)}

TPC was determined using Folin-Ciocalteu reagent as previously described [26]. Three hundred microliters of extract were mixed with $2.25 \mathrm{ml}$ of Folin-Ciocalteu reagent (previously diluted 10-fold with distilled water) and allowed to stand at room temperature for $5 \mathrm{~min} ; 2.25 \mathrm{ml}$ of sodium carbonate $(60 \mathrm{~g} / \mathrm{l})$ solution was added to the mixture. After $90 \mathrm{~min}$ at room temperature, absorbance was measured at 725 $\mathrm{nm}$ using spectrophotometer. Results were expressed as $\mathrm{mg}$ gallic acid equivalents in $1 \mathrm{~g}$ of dried sample (mg GAE/g).

\section{Determination of total flavonoid content (TFC)}

TFC was determined using colorimetric method described by Bakar et al. [26]. Half milliliter of the extract was mixed with $2.25 \mathrm{ml}$ of distilled water in a test tube followed by addition of $0.15 \mathrm{ml}$ of $5 \%$ $\mathrm{NaNO}_{2}$ solution. After $6 \mathrm{~min}, 0.3 \mathrm{ml}$ of a $10 \% \mathrm{AlCl}_{3}$ solution was added and allowed to stand for another 
http://wjst.wu.ac.th

$5 \mathrm{~min}$ before $1.0 \mathrm{ml}$ of $1 \mathrm{M} \mathrm{NaOH}$ was added. The mixture was mixed well with vortex. The absorbance was measured immediately at $510 \mathrm{~nm}$ using spectrophotometer. Results were expressed as mg rutin equivalents in $1 \mathrm{~g}$ of dried sample ( $\mathrm{mg} \mathrm{RE} / \mathrm{g}$ ).

\section{DPPH free radical scavenging assay}

The scavenging activity of the extracts was estimated by using 1,1-diphenyl-2-pycrylhydrazyl (DPPH) as a free radical model and a method adapted from Magalhães et al. [27]. An aliquot of $300 \mu \mathrm{L}$ of samples or control (80\% methanol) were mixed with $3.0 \mathrm{ml}$ of $500 \mu \mathrm{M}$ (DPPH) in absolute ethanol. The mixture was shaken vigorously and left to stand at room temperature for $30 \mathrm{~min}$ in the dark. The mixture was measured spectrophotometrically at $517 \mathrm{~nm}$. The free radical scavenging activity was calculated as follows: Scavenging effect $(\%)=[1-\{$ absorbance of sample/absorbance of control $\}] 100$. A standard of ascorbic acid was run using several concentrations ranging from 0.05 to $0.25 \mathrm{mg} / \mathrm{ml}$. A standard curve was then prepared by plotting the percentage $(\%)$ of free radical scavenging activity of ascorbic acid versus its concentration. The final result was expressed as $\mathrm{mg}$ ascorbic acid equivalent antioxidant capacity in $1 \mathrm{~g}$ of sample (mg AEAC/g).

\section{Statistical analysis}

All experiments were carried out in 3 replicates and presented as mean \pm standard deviation of (SD) using SPSS version 22.0.

\section{Results and discussion}

\section{Volatile oil analysis}

The composition of volatile oil of one plant differs according to the geographical region in which it is grown. This is due to different environmental or genetic factors. The content of oil of T. orientalis collected from different regions; e.g. Vietnam, Iran, China, Pakistan, Tunisia, Syria, India, Austria, and Nigeria, were previously reported (Table 2). Herein the composition of the oil distilled from Egyptian sample is reported. Thirty compounds could be identified in the oil samples obtained from fruits and leaves of the plant (Table 1). GC-MS analysis revealed that fruits are richer in monoterpenes $(62.5 \%)$ while leaves are richer in sesquiterpenes (57\%). Among the identified monoterpens; $\alpha$-pinene $(11.3 \%)$, $\beta$-pinene (3.8\%), $\beta$-myrecene $(9.6 \%)$, d-limonene $(7.6 \%)$, $\alpha$-terpinolene $(7.5 \%)$ are major monterpenes present in higher percentages in fruits than leaves. Moreover, the monoterpene esters; bornyl acetate $(4.5$ $\%)$ and geranyl acetate (9\%) are also detected in higher percentages in fruits. On the other hand, the sesquiterpene compounds namely $\beta$-elemene $(2.3 \%), \beta$-funebrene $(3 \%), \beta$-caryophyllene $(15 \%), \alpha$ humulene $(10.7 \%)$, germacrene-D $(5.9 \%)$ and $\alpha$-cedrol $(15.8 \%)$ are major sesquiterpenes found in higher percentages in leaves than fruits (Figure 1). A previous study [28] compared the composition of oil distilled from aerial parts of Egyptian and Saudi Arabian T. orientalis. Results look close to the present study, however, herein, a detailed analysis of oils separately distilled from leaves and fruits are reported. The composition of the hydro-distilled oil of $T$. orientalis growing in China was extensively discussed. It was stated that $\alpha$-pinene, $\Delta^{3}$-carene, $\alpha$-cedrol and $\alpha$ - and $\beta$-caryophyllene are the prevailing compounds with different concentrations in each sample. GC-MS analysis of the oil sample from Vietnamese $T$. orientalis leaves confirmed the presence of $\alpha$-pinene and $\alpha$-cedrol in major amounts. Similarly, $\alpha$-pinene and $\alpha$-cedrol are detected in major amounts in plants grown in Iran, Pakistan, Tunisia, Syria and India. On the other hand, oils distilled from plants grown in other localities e.g. Turkey, Austeria and Nigeria exhibit different components (Table 2). Due to variation between oil populations collected from variable areas, Dai et al. [14] classified these reports into 7 main groups according to the major components in each oil sample (Table 3). The present study explores the oil content of fruits and leaves of $T$. orientalis collected from Egypt. Results revealed that the predominant components are; $\alpha$ cedrol (15.8\%), $\beta$-caryophyllene (15\%), $\alpha$-humulene $(10.7 \%)$, d-limonene $(7.3 \%)$, $\alpha$-pinene $(6.9 \%), \beta$ myrecene $(5.9 \%)$ and $\alpha$-terpinolene $(5.2 \%)$ in leaves of the plant. Fruit oil, exhibited different composition with; $\alpha$-pinene $(11.3 \%), \alpha$-cedrol $(11.2 \%), \beta$-myrecene $(9.6 \%)$, geranyl acetate $(9 \%)$ and $\beta$-caryophyllen $(8.9 \%)$. Accordingly, the current study adds another class to those previously stated. 
http://wjst.wu.ac.th

Table 1 Major volatile oil components of $T$. orientalis leaves and fruits.

\begin{tabular}{|c|c|c|c|}
\hline \multirow{2}{*}{$\mathbf{R}_{\mathbf{t}}$} & \multirow{2}{*}{ Name } & \multicolumn{2}{|c|}{ Area\% } \\
\hline & & Fruit & Leaf \\
\hline 5.96 & $\alpha$-pinene* & 11.3 & 6.9 \\
\hline 6.21 & Camphene & 0.9 & nt. \\
\hline 6.69 & Sabinene & 0.3 & 1.1 \\
\hline 6.76 & $\beta$-pinene* & 3.8 & 0.5 \\
\hline 7.03 & $\beta$-myrecene* & 9.6 & 5.9 \\
\hline 7.32 & 1-phellandrene & 1.6 & 3 \\
\hline 7.4 & $\Delta^{3}$ - carene & nt. & 0.7 \\
\hline 7.58 & $\alpha$-terpinene & 0.5 & nt. \\
\hline 7.85 & d-limonene* & 7.6 & 7.3 \\
\hline 8.4 & $\gamma$-terpinene & 0.8 & \\
\hline 9.08 & $\alpha$-terpinolene* & 7.5 & 5.2 \\
\hline 10.73 & (3E,5Z)-1.3,5-Undecatriene & nt. & 1.6 \\
\hline 10.8 & 4-terpineol & 1.6 & 0.8 \\
\hline 11.11 & $\alpha$-terpineol & 0.8 & nt. \\
\hline 12.8 & 1-Bornyl acetate* & 4.5 & 1.9 \\
\hline 13.9 & Camphene* & 2.2 & 2.3 \\
\hline 14.1 & Neryl acetate & 0.5 & nt. \\
\hline 14.46 & Geranyl acetate* & 9 & 0.9 \\
\hline 14.69 & $\beta$-elemene* & 1.4 & 2.1 \\
\hline 15.12 & $\beta$-funebrene* & 1.9 & 3 \\
\hline 15.22 & $\beta$-caryophyllene* & 8.9 & 15 \\
\hline 15.37 & $\gamma$-elemene & 1.3 & 0.9 \\
\hline 15.7 & Trans- $\beta$-farnesene & 0.2 & nt. \\
\hline 15.8 & $\alpha$-humulene* & 5.7 & 10.7 \\
\hline 15.89 & Germacrene & 0.2 & 0.3 \\
\hline 16.08 & $\gamma$-curcumene & 1.1 & 1.5 \\
\hline 16.17 & germacrene-D* & 3.1 & 5.9 \\
\hline 16.76 & $\Delta$-cadinene & 0.5 & 1.3 \\
\hline 18.1 & $\alpha$-cedrol* & 11.2 & 15.8 \\
\hline 18.7 & t-Murolol & nt. & 0.5 \\
\hline Total identified & & $98 \%$ & $95.1 \%$ \\
\hline Total monoterpenes & & $62.5 \%$ & $38.1 \%$ \\
\hline Total sesquiterpenes & & $35.5 \%$ & $57 \%$ \\
\hline
\end{tabular}

nt: not detected, *Major components, Area \%: Peak area relative to total peak area \% 


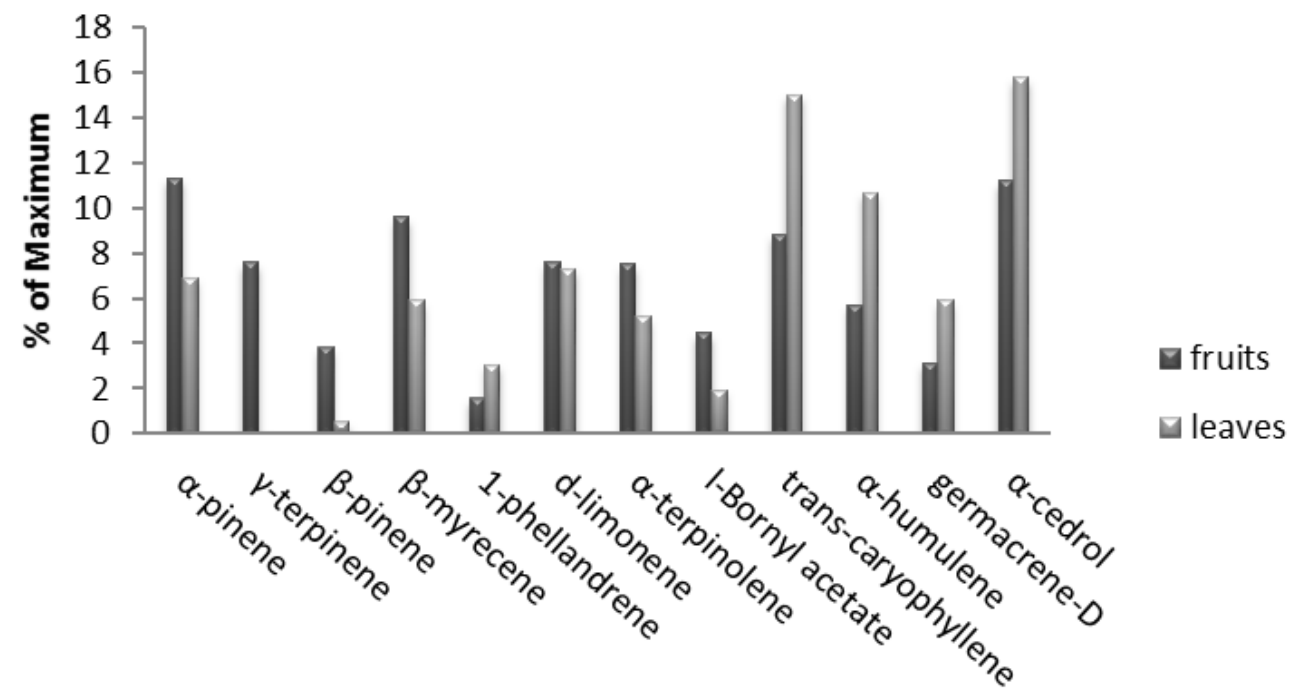

Volatile oil components

Figure 1 Relative percentage of the major volatile oil components in $T$. orientalis fruits and leaves.

Table 2 Oil composition of $T$. orientalis growing in different localities.

\begin{tabular}{|c|c|c|}
\hline Origin & Major constituents & Ref. \\
\hline China & $\begin{array}{l}\alpha \text {-pinene, } \Delta^{3} \text {-carene and } \alpha \text {-cedrol, terpinenyl acetate, cedrene, } \alpha \text { - and } \beta \text {-caryophyllene, } \alpha \text { - } \\
\text { humulene and d-limonene }\end{array}$ & [6-10] \\
\hline Iran & $\begin{array}{l}\alpha \text {-pinene, } \Delta^{3} \text {-carene and cedrol } \\
\alpha \text {-pinene, } \Delta^{3} \text {-carene, } \alpha \text {-cedrol, } \beta \text {-caryophyllene limonene and sabinene } \\
\alpha \text { - and } \beta \text {-pinene, } \Delta^{3} \text {-carene, } \alpha \text {-cedrol, } \beta \text {-phellandrene, } d \text {-limonene, } \alpha \text {-fenchene, } \alpha \text {-terpinolene and } \\
\text { sabinene } \\
\Delta^{3} \text {-carene, } \alpha \text {-pinene, cedrol, sabinene, } \alpha \text {-humulene }\end{array}$ & {$[11-13]$} \\
\hline Vietnam & $\alpha$-cedrol, $\alpha$-pinene, $\beta$-caryophyllene and $\beta$-selinene & {$[14]$} \\
\hline Pakistan & $\alpha$-pinene, $\Delta^{3}$-carene and $\alpha$-cedrol & {$[15,16]$} \\
\hline Austria & Camphor, fenchone, $\alpha$-thujone and $\beta$-thujone & {$[17]$} \\
\hline Nigeria & $\beta$-santalene, cedrol, fenchol and $\beta$-elemene & {$[18]$} \\
\hline India & $\alpha$-pinene, $\Delta^{3}$-carene, $\alpha$-cedrol, caryophyllene, $\alpha$-humulene, $\alpha$-terpinolene and terpinyl acetate & {$[19,20]$} \\
\hline Turkey & D-limonene, $\beta$-phellandrene, $\beta$-myrcene & [23] \\
\hline Tunisia & $\alpha$-pinene, $\beta$-phellandrene, $\alpha$-cedrol & {$[24]$} \\
\hline Syria & $\alpha$-pinene, $\Delta^{3}$-carene,$\alpha$-cedrol, caryophyllene, $\alpha$-humulene, terpinolene and limonene & {$[25]$} \\
\hline $\begin{array}{l}\text { Egyptian (leaf) } \\
\text { Egyptian (fruit) }\end{array}$ & $\begin{array}{l}\alpha \text {-cedrol, } \beta \text {-caryophyllene, } \alpha \text {-humulene, } d \text {-limonene, } \alpha \text {-pinene, } \beta \text {-myrcene and } \alpha \text {-terpinolene } \\
\alpha \text {-pinene, } \alpha \text {-cedrol, } \beta \text {-myrcene, geranyl acetate and } \beta \text {-caryophyllene }\end{array}$ & This s \\
\hline
\end{tabular}


http://wjst.wu.ac.th

Table 3 Classification of different populations of $T$. orientalis according to the predominant oil components.

\begin{tabular}{cll}
\hline Class & \multicolumn{1}{c}{ Major components } & Ref. \\
\hline Group-1 & $\alpha$-pinene, $\Delta^{3}$-carene, cedrol & \\
Group-2 & $\alpha$-cedrol, 3 -carene, $\beta$-caryophyllenen & \\
Group-3 & $\alpha$-cedrol, $\beta$-caryophyllenen, $\alpha$-caryophellene & \\
Group-4 & $\alpha$-pinene, 3 -carene, sabinene & \\
Group-5 & $\alpha$-thujone, $\beta$-thujone & \\
Group-6 & camphor, fenchone, $\alpha$-thujone & This study \\
Group-7 & $\alpha$-pinene, $\beta$-pinene, sabinene \\
Group-8 & $\alpha$-cedrol, $\beta$-caryophyllene, $\alpha$-humulene (in leaf) & $\alpha$-pinene, $\alpha$-cedrol and $\beta$-myrecene (in fruit) \\
\hline
\end{tabular}

Table 4 Total Phenolic, Total Flavonoids and DPPH Scavenging Ability of T. orientalis Leaves and Fruits.

\begin{tabular}{llll}
\hline Plant material & TPC $^{\mathrm{A}}$ & TFC $^{\mathrm{B}}$ & DPPH assay $^{\text {C }}$ \\
\hline T. orientalis leaf & $0.51 \pm 0.007$ & $0.3069 \pm 0.019$ & $1.2734 \pm 0.0022$ \\
\hline T. orientalis fruit & $0.75 \pm 0.007$ & $0.6267 \pm 0.026$ & $2.3516 \pm 0.0007$ \\
\hline
\end{tabular}

Values are presented in mean $\pm \mathrm{SD}(\mathrm{n}=3)$.

${ }^{\mathrm{A}}$ Total phenolic content was expressed as mg gallic acid equivalent in $1 \mathrm{~g}$ of dry sample $(\mathrm{mg} \mathrm{GE} / \mathrm{g})$.

${ }^{\mathrm{B}}$ Total flavonoid content was expressed as mg rutin equivalent in $1 \mathrm{~g}$ of dry sample (mg RE/g).

${ }^{\mathrm{C}} \mathrm{DPPH}$ free radical scavenging activity was expressed as mg ascorbic acid equivalent antioxidant capacity in $1 \mathrm{~g}$ of dry sample (mg AE/g).

\section{Total phenolic content (TPC)}

Folin-Ciocalteu reagent was used to determine total polyphenol in sample extract. Folin-Ciocalteu reagent consists of a yellow acidic solution containing complex polymeric ions formed from phosphomolybdic and phosphotungstic heteropolyacids. This reagent oxidizes phenolates resulting in the production of complex molybdenum-tungsten blue which can be detected spectrophotometrically at 725 $\mathrm{nm}$. TPC of the leaves was $0.51 \pm 0.007$ while in fruit was $0.75 \pm 0.007$ gallic acid equivalents in $\mathrm{mg} / \mathrm{g}$ plant material (Table 4).

\section{Total flavonoid content (TFC)}

Flavonoids are the most common and widely distributed group of plant phenolic compounds that are characterized by a benzo- $\gamma$-pyrone structure. Total flavonoid can be determined in the sample extracts by reaction with sodium nitrite, followed by the development of colored flavonoid-aluminum complex formation using aluminum chloride which can be monitored spectrophotometrically at $510 \mathrm{~nm}$. TFC of $T$. orientalis leaves was $0.3069 \pm 0.019$ while in fruit it was the double amount $(0.6267 \pm 0.026) \mathrm{mg}$ rutin equivalent in $1 \mathrm{~g}$ of dry sample (Table 4). 


\section{DPPH free radical scavenging assay}

The anti-oxidant activity, TPC and TFC of Indian T. orientalis were previously estimated [19-22]. Results indicated significant anti-oxidant activity of different parts of the plant. These findings come in great accordance with results of this study, which deals with the Egyptian conifer. In the present study, investigation of total antioxidant capacity was measured as the cumulative capacity of the compounds present in the sample to scavenge free radicals, using the 2,2-diphenyl-1-picrylhydrazyl (DPPH) reaction. The presence of antioxidant in the sample leads to the disappearance of DPPH radical chromogens which can be detected spectrophotometrically at $517 \mathrm{~nm}$. Leaves showed antioxidant activity of $1.2734 \pm 0.0022$ while the fruit was $2.3516 \pm 0.0007 \mathrm{mg}$ AEAC/g of dry sample. The antioxidant activity totally correlates with the total phenolic and flavonoid content with fruit showing the higher values.

Previous chemical investigation of $T$. orientalis leaves and fruits reported the isolation of volatile oil, flavonoids and diterpenes. Free radical scavenging and anti-elastase activities of flavonoids from the fruits of $T$. orientalis was previously reported and bioassay-guided fractionation of the $\mathrm{MeOH}$ extract of T. orientalis fruits using a DPPH (2,2-diphe- nyl-1-picrylhydrazyl) assay led to the isolation of 9 flavonoids; cupressuflavone, amentoflavone, robustaflavone, afzelin, $(+)$-catechin, quercetrin, hypolaetin 7-O- $\beta$-xylopyranoside, isoquercitrin and myricitrin [29]. Flavonoids previously reported in leaves were myricitrin, isoquercitrin, hypoletin-7-O- $\beta$-D-xylopyranoside, quercitrin, kaempferin, kaempferol, and amentoflavone. Comparative determination of TPC, TPC and DDPH radical scavenging activity of both leaves and fruit (Table 4) showed that fruit content of flavonoids $(0.6267 \pm 0.026 \mathrm{mg} \mathrm{RE} / \mathrm{g})$ is double the content of the leaves $(0.3069 \pm 0.019 \mathrm{mg} \mathrm{RE} / \mathrm{g})$ and also higher in TPC $(0.75 \pm 0.007 \mathrm{mg} \mathrm{GE} / \mathrm{g}$ in fruit compared to $0.51 \pm 0.007 \mathrm{mg} \mathrm{GE} / \mathrm{g}$ ) in leaves.

\section{Conclusions}

Comparative study of the oil composition of leaves and fruits of T. orientalis growing in Egypt revealed a significant difference in main components. Fruits are richer in monoterpenes, while leaves are richer in sesquiterpenes. Comparative study with previous reports of analysis of oils prepared from $T$. orientalis growing in different localities revealed qualitative and quantitative differences. This could be attributed to variation in climatic conditions, handling procedures or genetic factors. GC-Ms analysis revealed different concentrations of oil components which led to addition of other group to those previously reported (Table 3) [14]. Fruit extract exhibits higher antioxidant activity that could be clearly attributed to their higher TPC and TFC values. The extracts of leaves and fruits of T. orientalis could be a valuable material for pharmaceutical industry.

\section{References}

[1] TH Kim, H Li, Q Wu, HJ Lee and JH Ryu. A new labdane diterpenoid with anti-inflammatory activity from Thuja orientalis. J. Ethnopharmacol. 2013; 146, 760-7.

[2] N Zhang, DK Park and HJ Park. Hair growth-promoting activity of hot water extract of Thuja orientalis. BMC Complement. Altern. Med. 2013; 13, 9.

[3] EH Lee, DG Song, JY Lee, CH Pan, BH Um and SH Jung. Flavonoids from the leaves of Thuja orientalis inhibit the aldose reductase and the formation of advanced glycation endproducts. $J$. Korean Soc. Appl. Biol. Chem. 2009; 52, 448-55.

[4] S Emami, J Asili, Z Mohagheghi and MK Hassanzadeh. Antioxidant activity of leaves and fruits of Iranian conifers. Evid. Based Complement. Alternat. Med. 2007; 4, 313-9.

[5] A Singh and VK Singh. Molluscicidal activity of Saraca asoca and Thuja orientalis against the fresh water snail Lymnaea acuminata. Vet. Parasitol. 2009; 164, 206-10.

[6] H Lei, Y Wang, F Liang, W Su, Y Feng and X Guo. Composition and variability of essential oils of Platycladus orientalis growing in China. Biochem. Syst. Ecol. 2010; 38, 1000-6.

[7] YD Chen, SX Li, L Yang, ZY Jiang and NH Cui. Comparative study on chemical constituents of essential oils from several parts of Platycladus orientlais. Chem. Indust. Forest 1984; 4, 1-11. 
http://wjst.wu.ac.th

[8] TL Liu, Q Qiu, Y Zhao, YM Shen and J Wang. Study on chemical constituents of essential oil of Biota orientlais by GC-MS. J. Chin. Med. Mater. 2000; 23, 460-1.

[9] RH Hui, DY Hou, XY Liu, XC Li and HL Geng. Analysis of volatile components from leaf twigs in Biota orientalis with different extraction methods by gas chromatography-mass spectrometry. $J$. Chin. Mass Spectrom. Soc. 2006; 27, 226-31.

[10] H Lei, Y Wang, F Liang, W Su, Y Feng, X Guo and N Wang. Composition and variability of essential oils of Platycladus orientalis growing in China. Biochem. Syst. Ecol. 2010; 3, 1000-6.

[11] MK Hassanzadeh, M Rahimizadeh, BS Fazly Bazzaz, SA Emami and J Assili, Chemical and antimicrobial studies of Platycladus orientalis essential oils. Pharm. Biol. 2001; 39, 388-90.

[12] B Nickavar, G Amin and S Parhami. Volatile constituents of the fruit and leaf oils of Thuja orientalis L . grown in Iran. Z. Naturforsch. 2003; 58, 171-2.

[13] S Afsharypuor and B Nayebzadeh. Essential oil constituents of young stem, leaf and fruit of Platycladus orientalis (L.) Franco grown in Isfahan (Iran). J. Essent. Oil Res. 2009; 21, 525-28.

[14] DN Dai, TD Thang and IA Ogunwande. Terpene composition of three species of Gymnosperms from Vietnam. Am. J. Plant Sci. 2013; 4, 2031-8.

[15] M Riaz, MK Rashid and FM Chaudary. Volatile constituents of the leaves Pakistani Cupressus sempervirens and Thuja orientalis. Pak. J. Sci. Indust. Res. 1999; 42, 98-101.

[16] M Riaz, S Qamar, M K Rashid and FM Chaudary. Chemical composition of Thuja orientalis L. fruits at different stages of maturity. Pak. J. Sci. Indust. Res. 1999; 42, 188-91.

[17] R Chizzola, W Hochsteiner and S Hajek. GC Analysis of essential oils in the rumen fluid after incubation of Thuja orientalis twigs in the rusitec system. Res. Vet. Sci. 2004; 76, 77-82.

[18] IA Ogunwande, NO Olawore, KA Adeleke and O Ekundayo. Composition of the volatile oil of Thuja ori entalis L. from Nigeria. J. Trop. Forest Resour. 2003; 19, 41-7.

[19] S Guleria, A Kumar and AK Tiku. Chemical composition and fungitoxic activity of essential oil of Thuja orientalis L. grown in the north-western Himalaya. Z. Naturforsch. 2008; 63, 211-4.

[20] A An, M Sunanda, B Shubhangi, A Jain and M Manisha. Pharmacognostic, phytochemical, and pharmacological investigation on bark of Thuja orientalis Linn (Cupressaceae). J. Pharmacogn. Phytochem. 2016; 5, 111-3.

[21] ND Jasuja1, SK Sharma, R Saxena, J Choudhary, R Sharma and SC Joshi. Antibacterial, antioxidant and phytochemical investigation of Thuja orientalis leaves. J. Med. Plants. Res. 2013; 7, 1886-93.

[22] WA Shah and M Qadir. Chemical composition, antioxidant and antibacterial activity of Thuja orientalis essential oil. World J. Pharm. Sci. 2014; 2, 56-61.

[23] G Kayaa, R Karakaya, E Tilgel, M Sandikçı, E Yücel, G Çicek, Ö Kayır, H Akşit, İ Telci, A Güzel, M Elmastas and R Erenler. Essential oil constituents of Thuja orientalis berries. J. New Results Sci. 2014; 7, 1-6.

[24] I Amri, M Hanana, B Jamoussi and L Hamrouni. Chemical composition of Thuja orientalis L. essential oils and study of their allelopathic potential on germination and seedling growth of weeds. Arch. Phytopath. Plant Protect. 2014; 48, 18-27.

[25] MJ Khubeiz, G Mansour and B Zahraa. Antibacterial and phytochemical investigation of Thuja orientalis (L.) leaves essential oil from Syria. Int. J. Curr. Pharmaceut. Rev. Res. 2016; 7, 243-7.

[26] MF Abu Bakar, M Mohamed, A Rahmat and J Fry. Phytochemicals and antioxidant activity of different parts of bambangan (Mangifera pajang) and tarap (Artocarpus odoratissimus). Food Chem. 2009; 113, 479-83.

[27] LM Magalhães, M Segundo, S Reis and JL Lima. Automatic method for determination of total antioxidant capacity using 2,2-diphenyl-1-picrylhydrazyl assay. Anal. Chim. Acta 2006; 558, 310-8.

[28] ER Elsharkawy, H Aljohar and AM Donia. Comparative study of antioxidant and anticancer activity of Thuja orientalis growing in Egypt and Saudi Arabia. Br. J. Pharmaceut. Res. 2017; 15, 1-9.

[29] Xu GH, IJ Ryoo, YH Kim, SJ Choo and ID Yoo. Free radical scavenging and antielastase activities of flavonoids from the fruits of Thuja orientalis. Arch. Pharm. Res. 2009; 32, 275-82. 